and Registration and his detailed enumeration of Rhododendron cultivars -all recognised by his award of the Royal Horticultural Society's Victoria Medal of Honour in 1956.

A year after his return to the Edinburgh Garden in 1955 he succeeded Wright Smith as Regius Keeper. Immediately his energy and enthusiasm were thrown into rejuvenating botany and horticulture in the Garden, in Edinburgh, in Scotland and further afield. $\mathrm{He}$ relentlessly badgered authority to give him the necessary resources and so built a new herbarium and library in 1964 and new glasshouses in 1967. The staff was enlarged and better equipped, the outlook in taxonomy and horticulture remoulded and the training of horticulturists recast.

His continuing interest in botany in Scotland found an outlet in stimulating the post-war revival of the Botanical Society of Edinburgh but his much wider interest in world botany led to his advocacy of Edinburgh as the site of the Tenth International Botanical Congress. For this Congress in 1964 he shouldered much of the planning as general secretary. This Congress placed botany in Edinburgh before a wide audience, but in addition by travels and lectures, especially in North America, he formed strong personal links worldwide-especially as President of the International Association of Botanical Gardens 1964-69.

His outstanding devotion to Botany in Scotland was recognised by his much cherished appointment as Queen's Botanist in Scotland in 1967, as an Honorary Professor of Botany in the University of Edinburgh in 1968 and by the award of honorary DSc's by Edinburgh in 1971 and St Andrews in 1972 and the Patrick Neill Prize by the Royal Society of Edinburgh 1971-73.

His interest in writing and horticultural and botanical history found an outlet in his Story of the Royal Horticultural Society 1804-1968 in 1969 and (with W. H. Brown) History of the Royal Botanic Garden, Edinburgh 1670-1970 published in time for the garden's tercentenary celebrations. Following his retirement in 1970 he wrote a detailed account of the plant collecting travels of Ludlow and Sherriff-A Quest of Flowers.

Throughout his professional life he had a deep love of the arts especially literature, music and painting of which he had a discriminating collection. In his retirement he found more time for these pursuits and served as Chairman and then as a member of the Governors of the Edinburgh College of Art.

Harold Fletcher was possessed of a most remarkable blend of science and the arts intermingled with a strong human compassion. His taxonomy was science tinged with art, his administration science guided by humanity. Throughout his life he drove himself hard and was loyally and very knowledgeably supported and encouraged by his wife Betty and by his son and daughter.

D. M. Henderson

\section{John Marwick}

DR JoHN MARWICK, the leading palaeontologist in New Zealand during the middle decades of the twentieth century, died in Hawkes Bay, New Zealand, on 16 August 1978, at the age of 87.

The son of an Orkney wheelwright who migrated to Otago in the eighteeneighties, Marwick was educated at Oamaru, attending Waitaki Boys' High School, where the rector, $\operatorname{Dr} R$. H. Don, was changing the bias of the curriculum from classical to scientific, stimulating an interest in geology by classes and excursions such as were seldom available to secondary school boys. Entering the teaching profession, Marwick attended Otago University, graduating M.A. with first class honours in geology, and winning the Ulrich Memorial Medal in mineralogy and petrography, thereafter teaching in South Canterbury for two years before the outbreak of World War I. In the Middle East (1916-19) he served in the Camel Corps and N. Z. Mounted Field Ambulance, was twice wounded and was awarded the Military Medal.

On his return from the war, Marwick was appointed to work in palaeontology at the New Zealand Geological Survey (then under the Mines Department, but later a division of the Department of Scientific and Industrial Research). His research on Tertiary molluscs led in 1924 to the award of D.Sc. (University of New Zealand) for a revision of New Zealand Veneridae (Bivalvia).

Between 1921 and 1976 he published about 125 papers, reviews, and bulletins, his research continuing for 20 years after his official retirement from the Geological Survey (as Chief Palaeontologist) in 1952 . He brought a sound objective judgement to the study of the systematics and biostratigraphy of New Zealand Bivalvia and Gastropoda. His revisions (illustrated by his own pen and ink drawings) of Struthiolariidae, Naticidae, Volutidae, Veneridae, Cardiidae and his monographs of Tertiary faunas, notably the Danian (Palaeocene) Wangaloan fauna, described jointly with the late $\mathrm{Dr} \mathrm{H}$. J. Finlay, earned John Marwick a world reputation as a student of fossil Mollusca.

With his colleague Finlay, who pioneered study of New Zealand Cretaceous and Cenozoic Foraminifera at the Geological Survey, Marwick was also responsible for defining and improving the standard sequence of local biostratigraphic stages that have been of great value in geological mapping in New Zealand. As a primarily Cenozoic palaeontologist, he regarded his occasional deviations into the Mesozoic as somewhat amateurish, yet his contributions include a standard reference work on New Zealand Triassic and Jurassic fossils. On the other hand he welcomed field work in a Geological Survey faced by the hard times and stringencies of the great economic depression, when Marwick was expected to assist in geological mapping and writing diverse reports with little relevance to palaeontology. He gained great satisfaction from descriptive geomorphology and stratigraphy, so that his publications in these subjects, for instance on the physiography and structure of the Rotorua-Taupo volcanic zone (with H.E. Fyfe) and on the geology of Te Kuiti district must always rank high among his achievements.

Dr Marwick might well have become Director of the Geological Survey, but although he served as Acting-Director on occasion, he preferred to remain in his palaeontology laboratory. On several occasions he lectured in geology at Victoria University of Wellington (then a college of the University of New Zealand) when his close friend $\mathrm{Dr}$ C. A. Cotton (later Sir Charles), well known for his geomorphology text books, was overseas on sabbatical leave, and he also served as external examiner for higher degrees. He took an active part in the Royal Society of New Zealand, which had awarded him the Hamilton Prize for beginners in science (1926) and elected him a Fellow in 1935; he was awarded both the Hector and the Hutton Memorial Medals of the Society for his contributions to palaeontology. He served on Council, was Honorary Editor of the Society's Transactions (1938-46) and was elected Vice-President (1950-52) but declined nomination as President.

Especially during the search for petroleum in New Zealand between the wars and after 1945, Marwick introduced many overseas geologists to New Zealand stratigraphy and he recalled with pleasure his excursions to fossil localities with Drs T. Wayland Vaughan, Axel A. Olsson, F. A. Singleton, and other visiting palaeontologists.

Jack Marwick was an unselfish man of high integrity, whose humanity and altruism made him a father figure to the many young geologists he helped in their careers; while his sincerity, good humour, and broad-based culture earned the friendship and respect of his colleagues.

C. A. Fleming 